\title{
PENGARUH PAJAK BUMI DAN BANGUNAN TERHADAP PENDAPATAN ASLI DAERAH KOTA PALOPO
}

\section{A.TENDRI ESSE IRHAM, SAMSUL BACHRI, M. HALIM}

\begin{abstract}
ABSTRAK
Pajak Bumi dan Bangunan adalah pajak Negara yang sebagian besar penerimaannya merupakan pendapatan daerah yang antara lain dipergunakan untuk penyediaan fasilitas yang juga dinikmati oleh pemerintah pusat dan pemerintah daerah, diantaranya memberikan sumbangsih terhadap pendapatan asli daerah. Variabel dalam penelitian ini terdiri atas dua yaitu: 1) Pajak Bumi dan Bangunan (X) serta 2) Pendapatan Asli Daerah (Y)

Penelitian ini bertujuan untuk mengetahui seberapa besar pengaruh pajak bumi dan bangunan terhadap pendapatan asli daerah Kota Palopo. Metode Penelitian yang digunakan yaitu metode deskriptif, melalui data yang dikumpulkan untuk kemudian diolah, dianalisis, dan diproses lebih lanjut. Data sekunder yang diperoleh dari informasi dan data lainnya diolah dengan teknik regresi sederhana dengan bantuan program SPSS.

Berdasarkan hasil penelitian, ditemukan persamaan regresi linear sederhana $Y=-$ 330,29+265,16X, dimana pajak bumi dan bangunan memberi pengaruh sebesar 14,123 persen bagi pendapatan asli daerah.

Kesimpulannya bahwa Pajak Bumi dan Bangunan berpengaruh terhadap Pendapatan Asli Daerah di Kota Palopo, sehingga pemerintah dituntut untuk lebih meningkatkan lagi kebijakannya yang berhubungan dengan Pajak Bumi dan Bangunan.
\end{abstract}

Kata kunci: Pajak Bumi dan Bangunan, Pendapatan Asli Daerah

\section{Pendahuluan}

\section{Latar Belakang}

Dalam menghadapi era globalisasi dan pertumbuhan ekonomi serta kemajuan teknologi dan ilmu pengetahuan yang begitu cepat, sehingga memaksa semua lapisan masyarakat untuk bersaing dan bekerja keras dalam memenuhi kebutuhannya baik primer, sekunder maupun tersier untuk mengikuti laju modernitas yang semakin global. Dimana-mana terdapat bangunan-bangunan seperti gedung, perkantoran, rumah makan, swalayan, mini market, dan lain-lain. Hal ini akan sangat berpengaruh terhadap pendapatan asli daerah yang diperoleh melalui pembayaran pajak sebagai salah satu perwujudan kewajiban Negara serta ikut berperan dalam pembangunan. Untuk meningkatkan penerimaan daerah, maka pemerintah kota harus mengoptimalkan sumber-sumber pendapatan daerah serta kesadaran masyarakat untuk membayar pajak melalui peningkatan motivasi, penerangan, penyuluhan, dan pendidikan.

Kontribusi pajak bumi dan bangunan terhadap kelangsungan pelaksanaan pembangunan yang terangkum dalam dana perimbangan walaupun cukup besar nilainya dianggap tidak cukup untuk menopang pendapatan daerah 
Masalah yang tengah dihadapi oleh pemerintah daerah adalah masih lemahnya kemampuan pendapatan daerah untuk menutupi biaya dalam melaksanakan belanja pembangunan daerah yang setiap tahun meningkat. Hal inilah yang menarik penulis untuk melakukan penelitian mengenai Pengaruh Pajak Bumi dan Bangunan terhadap Pendapatan Asli Daerah Kota Palopo. Masalah Penelitian ini adalah Seberapa besar pengaruh Pajak Bumi dan Bangunan terhadap Pendapatan Asli Daerah Kota Palopo?. Tujuan Penelitian adalah untuk mengetahui dan menganalisis pengaruh Pajak Bumi dan Bangunan terhadap Pendapatan Asli Daerah Kota Palopo.

\section{Metode Penelitian}

Tempat dan Waktu Penelitian

Penelitian ini dilaksanakan pada Kantor Dinas Pengelolaan Pendapatan Keuangan dan Aset Daerah (DPPKAD) Kota Palopo yang didasarkan pada pertimbangan bahwa yang melaksanakan penagihan Pajak Bumi dan Bangunan di Kota Palopo adalah Kantor DPPKAD Kota Palopo, sedangkan waktu penelitian dilakukan selama 2 (dua) bulan mulai dari tanggal 28 Februari sampai dengan 28 April 2012.

Jenis dan Sumber Data

Jenis Data

1) Data Kuantitatif, data yang dapat dihitung

2) Data Kualitatif, data yang tidak dapat dihitung

\section{Sumber Data}

Data Sekunder, merupakan data yang diperoleh dari informasi tertulis lainnya yang ada hubungannya dengan penulisan ini.

\section{Metode Pengumpulan Data}

Metode pengumpulan data yang digunakan dalam penelitian ini adalah : (a) Penelitian Lapangan; Penelitian yang dilakukan dengan jalan pengamatan langsung kelapangan atau objek penelitian dengan cara mengadakan wawancara dengan pimpinan atau staf, Penelitian Kepustakaan; Penelitian yang dilakukan dengan cara mencari reverensi yang berupa bukubuku, majalah, surat kabar, buku-buku lain yang ada hubungannya dengan masalah yang dibahas, serta mengumpulkan data yang telah didokumentasikan oleh Instansi atau Dinas terkait

\section{Metode Analisis Data}

Bertitik tolak dari masalah dan hipotesis yang telah dikemukakan sebelumnya maka dalam membahas dan menganalisa permasalahan sekaligus membuktikan hipotesis maka penulis menggunakan metode regresi linear sederhana, dengan formulasi sebagai berikut : Y $=\mathrm{a}+\mathrm{bx}$ Dimana : 
$\mathrm{Y}=$ Pendapatan Asli Daerah $\mathrm{x}=$ Jumlah Pajak

Bumi dan Bangunan

$\mathrm{a}=$ Konstanta

$\mathrm{b}=$ Parameter $\mathrm{x}$ yang diukur

Selanjutnya untuk mengetahui hubungan realisasi penerimaan bagi hasil Pajak Bumi dan Bangunan Kota Palopo terhadap peningkatan Pendapatan Daerah Kota Palopo, maka digunakan persamaan korelasi sebagai berikut $: \mathrm{r}=\frac{n \sum X Y-\left(\sum X\right)\left(\sum Y\right)}{\sqrt{n \sum X^{2}-\left(\sum X\right)^{2}} \sqrt{n \sum Y^{2}-\left(\sum Y\right)^{2}}}$

Keterangan :

$\mathrm{r}=$ Koefisien Korelasi

$\mathrm{X}=$ Pajak Bumi dan Bangunan

$\mathrm{Y}=$ Pendapatan Asli Daerah

\section{Hasil Penelitian Dan Pembahasan}

Hasil Persamaam Regresi

Tabel 4

Hubungan antara PBB dengan besarnya Pendapatan Daerah (dalam jutaan rupiah)

\begin{tabular}{|l|l|l|l|l|}
\hline Variabel(X) & $\begin{array}{l}\text { Koefisien } \\
\text { Regresi }\end{array}$ & $\begin{array}{l}\text { Nilai } \\
\text { Koefisien } \\
\text { Regresi }\end{array}$ & $\mathrm{t}$ (Hitung) & $\begin{array}{l}\text { Probabilitas ( } \\
\mathrm{p})\end{array}$ \\
\hline $\mathrm{X}$ & $\mathrm{b}_{1}$ & 265,16 & 3,758 & 0,064 \\
\hline Konstanta & $\mathrm{b}_{\mathrm{o}}$ & $-330,29$ & & 0,765 \\
\hline $\mathrm{t}$ (hitung) & & 14,123 & & \\
\hline $\mathrm{r}^{2}$ & & 0,875 & $87,50 \%$ & \\
\hline $\mathrm{r}$ & & 0,935 & $93,50 \%$ & \\
\hline
\end{tabular}

Sumber : Lampiran SPSS Versi 16

Berdasarkan tabel di atas, maka dapat diketahui koefisien variable bebas dan nilai konstan, sehingga dapat disusun persamaan regresi linear sederhananya yaitu : $Y=\mathbf{- 3 3 0 , 2 9}+\mathbf{2 6 5 , 1 6 X}$, artinya apabila Pajak Bumi dan Bangunan sama dengan nol maka Pendapatan Asli Daerah akan mengalami penurunan sebesar Rp -330,29 dan apabila sistem pemungutan PBB dioptimalkan maka PAD akan meningkat sebesar Rp 265,16.

$\mathrm{b}_{0}=-330,29$ artinya apabila Pajak Bumi dan Bangunan pada Kantor Dinas Pendapatan Pengelola Keuangan dan Aset Daerah sama dengan nol, maka Pendapatan Asli Daerah menurun sebesar Rp -330,29 $b_{1}=265,16$ artinya ada pengaruh yang signifikan antara Pajak Bumi dan Bangunan dengan Pendapatan Asli Daerah. Hal ini berarti apabila Pajak Bumi dan Bangunan dapat ditingkatkan pemungutan agar lebih efesien dan efektif maka akan meningkatkan Pendapatan Asli Daerah yang lebih besar yaitu sebesar Rp 265,16. 
Analisis Koefisien Determinasi $\left(\mathrm{R}^{2}\right)$

Tabel 5

Hasil Analisis Koefisien Determinasi Model

Summary

\begin{tabular}{|c|c|c|c|c|}
\hline Model & $\mathrm{R}$ & R Square & \begin{tabular}{ll|} 
Adjusted & $R$ \\
Square & \\
\end{tabular} & $\begin{array}{l}\text { Std. Error of the } \\
\text { Estimate }\end{array}$ \\
\hline 1 & $.936^{\mathrm{a}}$ & .876 & .814 & 14557.19671 \\
\hline
\end{tabular}

a.Predictors : (Constant), X

Dari tabel diatas, diperoleh nilai $\mathrm{R}$ (Korelasi) sebesar 0,936 ini menunjukkan bahwa antar variable Pajak Bumi dan Bangunan memiliki hubungan yang sangat kuat dengan variable Pendapatan Asli Daerah.

Dalam penelitian ini besarnya koefisien determinasi $\left(\mathrm{R}^{2}\right)$ sebesar 0,876 atau 87,60 persen. Sehingga dapat dikatakan bahwa 87,60 persen variasi variable Pendapatan Asli Daerah (Y) pada model dapat diterangkan oleh variable Pajak Bumi dan Bangunan (X) sedangkan sisanya dipengaruhi oleh faktor lain yaitu sebesar 0,125 atau $12,50 \%$

\section{Penutup}

Kesimpulan penelitian ini adalah, dimana : Y =-330,29 + 265,16X; (a) bo $=-330,29$ artinya apabila Pajak Bumi dan Bangunan sama dengan nol maka Pendapatan Asli Daerah Kota Palopo diprediksi akan munurun sebesar $\mathrm{Rp}-330,29$, (b) $\mathrm{b}_{1}=265,15$ artinya ada pengaruh yang signifikan antara Pajak Bumi dan Bangunan dengan Pendapatan Asli Daerah. Hal ini berarti apabila pemungutan Pajak Bumi dan Bangunan lebih ditingkatkan terutama dari sistem penagihan yang diperketat maka akan meningkatkan Pendapatan Asli Daerah sebesar Rp 265,15, (c) $r=0,935$ artinya bahwa Pajak Bumi dan Bangunan memiliki pengaruh yang sangat kuat terhadap Pendapatan Asli Daerah atau mendekati 1, (d) $r^{2}=0,875$ artinya bahwa variable independen Pajak Bumi dan Bangunan mempunyai pengaruh yang cukup signifikan terhadap peningkatan Pendapatan Asli Daerah sebesar 0,875 atau 87,50 \% sedangkan sisanya 0,125 atau $12,50 \%$ dipengaruhi oleh faktor lain. Adapun Saran yang dapat penulis sampaikan sehubungan dengan hasil pembahasan diatas adalah bahwa variabel bebas yang terdiri atas Pajak Bumi dan Bangunan berpengaruh kuat terhadap peningkatan Pendapatan Asli Daerah Kota Palopo untuk itu pemerintah dituntut untuk lebih meningkatkan lagi kebijakannya yang berhubungan dengan variable tersebut.

\section{Daftar Pustaka}

Adrian, Ichwan. 2008. Penulisan Laporan Penelitian untuk Skripsi. Akuntansi. Fakultas Ekonomi Universitas Widyatama. Bandung. 
Departemen Keuangan Republik Indonesia, 1993. Uraian Jabatan Struktural dan Pelaksanaan Organisasi pada Direktorat Jenderal Pajak Bumi dan Bangunan Kantor Pusat Direktorat Jenderal Pajak, Jakarta.

Elmi, Bachrul. 2002, Keuangan Pemerintah Daerah Otonom di Indonesia. Penerbit Universitas Indonesia (III-Press), Jakarta.

Halim, Abdul, 2001, Bunga Rampai Keuangan Daerah. Yogyakarta.

Ismawan, Indra, 2001, Memahami Reformasi Perpajakan 2000, Jakarta.

Khusaini, Mohammad, 2006, ekonomi Publik : desentralisasi Fiskan dan Pembangunan Daerah Penerbit BPFE UMBRA W, Malang.

Mardiasmo, 2002, Otonomi dan Manajemen Keuangan Daerah : Serial Otonomi Daerah. Penerbit Andi Yogyakarta, Yogyakarta.

Mardiasmo. 2006, Perpajakan.

M. Udin, risma, 2005, Pembiayaan Pembangunan Pemerintah Daerah Kabupaten Enrekang. Skripsi UNHAS, Makassar, Tidak dipublikasikan.

M. Zain. 2006. Ekonomi Publik: Desentralisasi Fiskal dan Pembangunan Daerah Penerbit BPFE UMBRA W, Malang.

Republik Indonesia, Undang-Undang Nomor 12 Tahun 1985 tentang Pajak Bumi dan Bangunan.

Resmi, Siti. 2006. Perpajakan Teori dan Kasus.

Soemitro, Rochmat, 1994. Dasar-Dasar Hukum Pajak Pendapatan, Bandung

Soemitro, Rochmat, 1997. Asas dan Dasar Perpajakan, Bandung.

Tim Penyusun, 1992. Direktorat Jendral Pajak dan Yayasan Bina Pembangunan, Jakarta.

Undang-Undang Nomor 12 Tahun 1994 tentang perubahan atas Undang-Undang Nomor 12 tahun 1985 tentang Pajak Bumi dan Bangunan.

Undang-Undang Nomor 25 Tahun 1999, tentang Perimbangan Keuangan antara Pemerintah Pusat dan Pemerintah Daerah. 
Undan-Undang Nomor 34 tahun 2000, tentang perubahan atas Undang-Undang Nomor 18 tahun 1987 tentang Pajak Daerah dan Retribusi Daerah

Undang-Undang Nomor 104 tahun 2000, tentang Dana Perimbangan

Undang-Undang Nomor 65 tahun 2001, tentang Pajak Daerah

Undang-Undang Nomor 6 tahun 2001,tentang Retribusi Daerah

Undang-Undang Nomor 33 Tahun 2004 tentang perimbangan Keuangan antar Pemerintah Pusat dan Pemerintah Daerah

Undang-Undang Nomor 13 tahun 2006, tentang Kelompok Pendapatan Dana Perimbangan

Undang-Undang Nomor 33 tahun 2004 tentang perimbangan Keuangan antara Pemerintah Pusat dan Pemerintah Daerah.

Undang-Undang Nomor 12 Tahun 1985 tentang Pajak Bumi dan Bangunan, Jakarta.

Undang-Undang Nomor 80 tahun 2007 tentang Tata Cara Pelaksanaan Hak dan Kewajiban Perpajakan. 